Professor Kolstø har arbeidet som lektor i skoleverket og arbeider nå med lærerutdanning ved Universitetet

i Bergen. Hans forskningsinteresser knytter seg til betingelser for at naturfagundervisning skal fungere

allmenndannende. Spesielt forsker han på hvordan praktisk arbeid i naturfag kan bidra til $\emptyset$ kt forståelse for

naturvitenskapenes egenart og fremme elevenes evne til å lese, samtale og skrive om naturfaglige emner.

STEIN DANKERT KOLST $\varnothing$

Institutt for fysikk og teknologi, Universitetet i

Bergen, Norge

kolsto@ift.uib.no

\title{
Vektlegging av lesing i naturfaget. Del 2: Hvordan fremme elevens kompetanse i å lese naturfaglige tekster?
}

\begin{abstract}
This article offers a tool-kit for science teachers reading instruction in science. The tool-kit is based on the importance of knowledge of text structures and skilled use of reading strategies for reading comprehension. Furthermore, the tool-kit takes into account the characteristics of the nature of science and scientific texts. By drawing upon insights from research on reading and reading instruction, the article directs attention to research which concludes that proper instruction increase students' competency in reading expository texts with understanding. The article thus concludes that, in order to induce a change in school science towards increased focus on reading scientific texts, competencies related to reading need to be included among the learning goals in the science curriculum.
\end{abstract}

\section{INTRODUKSJON}

Naturfagopplæringen i skolen har som mål å fungere allmenndannende. Dette innebærer at elevene skal forberedes til å kunne delta i ulike typer situasjoner hvor naturfaglig kunnskap og ekspertise inngår. I den nye norske læreplanen i naturfag påpekes det eksplisitt at naturfaget skal "gi den enkelte et grunnlag for deltagelse i demokratiske prosesser i samfunnet" (Kunnskapsdepartementet, 2006 s.1). Naturvitenskapelig kunnskap og argumentasjon inngår i beslutningsgrunnlaget i en mengde saker i politikk, næringsliv og hverdag (Ryder, 2001). Med en samlebetegnelse omtales ofte slike saker som sosiovitenskapelige. Aktuelle eksempler er kontroverser knyttet til klimaproblematikk, genmodifiserte jordbruksprodukter, stamcelleforskning og regelverk for miljøgifter og ulike typer stråling. I slike saker er det ikke nok å vurdere om en risiko bør tillates eller ikke, eller om en skal kjøpe en bestemt vare eller tjeneste. Hvis debatter og beslutninger skal grunngis, må en også vite noe om hva risikoen består i, og om det er en risiko (Kolstø, 2000). Leting etter svar på slike spørsmål tilhører naturvitenskapens kunnskapsdomene. Lesing av tekster med naturfaglig innhold blir dermed viktig for aktiv og kunnskapsbasert deltagelse og beslutningstaking i sosiovitenskapelige saker. Informasjon og debatter knyttet til slike saker finner en bl.a. i skriftlige media som aviser og Internett. Eksempler på aktuelle tekster er artikler og debattstoff om nye forskningsresultater, miljøutredninger, forklaringer av faglige begrep og forskningsrapporter. Det å kunne lese fagtekster med forståelse blir løftet frem som en viktig kompetanse både i forarbeidene til den norske skolereformen "Kunnskapsløftet" (Utdannings- og forskningsdepartementet 2003; 2004) og i de OECD-initierte PISA-undersøkelsene (Kjærnsli Lie, Olsen \& Roe, 2007; Lie, Kjærnsli, Roe \& Turmo, 2001). 
Lesing er en sentral kompetanse for å kunne sette seg inn i saker og argumenter, men også for å kunne tilegne seg ny aktuell kunnskap i naturfag etter endt skolegang. I tillegg til lærerens forklaringer er skriftlige tekster elevenes viktigste kilde til naturfaglig kunnskap også i opplæringen. Lesekompetanse er derfor viktig også for elevenes læring i naturfag underveis i utdanningsløpet. Det er derfor naturlig å spørre hvilke utslag lesingens sentrale posisjon i opplæringens mål har fått for naturfagets rammer og innhold. Denne artikkelen er den andre i en serie på to som undersøker denne problemstillingen. Den første artikkelen beskriver den foreliggende situasjonen og hva som kan gjøre det krevende å lese naturfaglige tekster med forståelse. Jeg hevdet der at vi har flere indikasjoner på at mange elever strever med å lese naturfaglige tekster, og at det heller ikke ser ut til å være noen tradisjon for leseopplæring i naturfaget. Jeg presenterte også en gjennomgang av den nye norske læreplanen i naturfag hvor jeg konkluderte med at målsettinger for lesekompetanse nærmest er fraværende i de formulerte kompetansemål.

På bakgrunn av resultatene i første artikkel vil jeg fremholde at leseopplæring bør gis økt oppmerksomhet i naturfaget. I denne andre av de to artiklene vil jeg derfor diskutere hvordan elevenes kompetanse i å lese naturfaglige tekster kan fremmes. På basis av resultater fra forskning på leseopplæring vil jeg først påpeke at opplæring i lesing av fagtekster er mulig. Jeg vil så beskrive hva leseopplæring kan innebære i praksis. Med utgangspunkt i innsikter fra leseforskning og kunnskaper om naturfagenes egenart vil jeg legge frem et forslag til fokus for leseopplæring i naturfag som inkluderer ulike naturfaglige tekstsjangre og konkrete mål for lesestrategier.

\section{NATURFAGETS ROLLE I LESEOPPLARINGEN}

Det å kunne avkode ord, altså å kunne lese alle enkeltord som inngår i en tekst, innebærer ikke nødvendigvis at en tekst gir leseren mening. Innen leseforskning er det i dag enighet om at det å lese er en interaktiv prosess der leseren utvikler sin egen oppfatning eller tolkning av teksten basert på tekstens innhold, forkunnskaper samt forventninger til teksten (Dole, Duffy, Roehler \& Pearson, 1991; Gregg \& Sekers, 2006; Langer, 1986; Maagerø \& Tønnesen, 2006; Norris \& Phillips, 2003). Lesing av naturfaglige tekster med forståelse er derfor en aktiv prosess.

Når mange elever strever med å lese naturfaglige tekster, hva er så forutsetningene for å kunne lese fagtekster med forståelse, og hvilke av elevenes uhensiktsmessige lesevaner bør det tilligge naturfagets mandat og gripe tak i? Innen et interaktivt syn på lesing blir elevens forkunnskaper, inkludert naturvitenskapelig kunnskap, viktig. I en kjent oversiktsartikkel peker Dole m.fl. (1991) på at utover relevant fagkunnskap er leserens generelle kunnskap om verden og om sjangeren viktig. I tillegg er leserens ferdigheter i bruk av ulike lesestrategier samt motivasjon og selvbilde av betydning (Helgevold \& Engen, 2006; Mortensen-Buan, 2006). Opplæring i relevant naturvitenskapelig fagkunnskap er en selvfølgelig del av naturfaget. Generell kunnskap om verden vil ikke primært være naturfaglærers oppgave å utvikle hos elevene, selv om dette klart inngår i skolens mandat. Derimot vil sjangrene som skal leses være fagavhengige og kunnskap om naturfaglige sjangere er derfor innenfor det som bør være naturfagets ansvar. Relevansen av ulike læringsstrategier vil variere mindre mellom de ulike fagene, men selvstendig overføring av kunnskap til nye situasjoner er en stor utfordring for mange elever (Anderson, Simon, \& Reder, 1996). Dette tilsier at det er avgjørende viktig at naturfaget trener elevene i bruk av læringsstrategier i møte med naturfaglige tekster. Viktigheten av å fokusere på sjangre og lesestrategier understrekes også av Skjelbred (2006):

Noe av det som skiller gode og dårlige lesere, er nettopp evnen til å tilpasse lesemåten ut fra sjanger og formål, til å benytte ulike lesestrategier. Dårlige lesere leser alle tekster på samme måte. Å loere å lese er dermed også å sosialiseres inn i ulike lesemåter. Sjangrer gir normer for hwordan tekster skal/kan leses. 
Leserens forventninger til teksten, basert på kunnskaper om sjangeren og dens aktuelle kontekst, blir således viktig for tolkning og forståelse. Videre i denne artikkelen vil jeg derfor bygge på antagelsen om at naturfaget bør inkludere kunnskap om ulike naturfaglige sjangre samt kompetanser til å bruke ulike lesestrategier i møte med disse.

\section{ER DET MULIG $\AA$ L LARE ELEVENE $\AA$ L LESE FAGTEKSTER MED FORSTÅELSE?}

I en artikkel om elevers lesing av fagtekster hevder Helgevold og Engen (2006) at Mange elever blir passive lesere, rett og slett fordi de ikke vet hva det går an å gjøre før, under og etter lesing. Slik kan de lett miste tro på egen lese- og loereevne.

Hvis vi mener det er ønskelig at elevene blir flinkere til å lese naturfaglige tekster, finnes det støtte i litteraturen for at opplæring faktisk kan fremme elevers lesekompetanse? I den nevnte oversiktsartikkel diskuterer Dole m.fl. (1991) forskning knyttet til opplæring i lesing med forståelse. I tillegg til viktigheten av å identifisere egen forhåndskunnskap innen emnet en skal lese om, identifiserer Dole m.fl. (1991) fem hovedtyper lesestrategier som hevdes å fremme forståelse:

Strategi 1: Bestemme viktighet. Denne strategien innbærer bruk av egen forhåndskunnskap til å vurdere innholdet i en tekst, bestemme hovedpoeng samt bruke kunnskaper om forfatterståsted, intensjoner og målsettinger til støtte i vurdering av viktighet. I tillegg innebærer den bruk av kunnskap om tekstens struktur til å identifisere og organisere informasjonen i teksten.

Strategi 2: Oppsummere informasjon. Dette innebærer at leseren arbeider med å transformere innholdet gjennom for eksempel å gjenta innholdet med egne ord. Dette krever evne til å se gjennom større tekstbrokker, velge ut, fortette og integrere informasjon i teksten, og derigjennom skape en ny sammenhengende tekst som gitt innholdsrelevante kriterier gjenskaper innholdet i den leste teksten.

Strategi 3: Trekke slutninger. Strategien innbærer aktiv sammenlikning av det en leser med egen forkunnskap og med innholdet i andre passasjer i en tekst, for så å bruke sammenlikningene til å trekke slutninger angående tekstens innhold og verdi. Det å trekke slike slutninger en kjerneaktivitet for å skape forståelse under lesing.

Strategi 4: Generere spørsmål. Dette innebærer at leseren i alle faser av lesingen utvikler spørsmål om teksten innhold, betydning og verdi. De hevder at forskningen viser at strategien medfører bearbeiding av teksten på dypere nivå.

Strategi 5: Overvåke egen forståelse. Denne strategien har to aspekt. Det første er å ha oppmerksomhet mot egen forståelse underveis i lesingen og å kunne oppdage når egen forståelse av teksten blir mangelfull. Dette aspektet innebærer og bygger på bevissthet om formålet med lesingen, vurdering av viktighet av ulik informasjon i teksten samt det å stille seg selv spørsmål underveis om det en leser (Bryant, Ugel, Thomson \& Hamff, 1999). Det andre aspektet er å gjøre bruk av reparasjonsstrategier når en har oppdaget mangelfull forståelse av en passasje, for eksempel gjennom repetert lesing av foregående avsnitt. Flere regner bruk av overvåking som det mest sentrale kjennetegn på gode lesere (Dole m.fl., 1991; Mortensen-Buan, 2006). Svake lesere vil typisk hverken oppdage egne forståelsesproblemer eller være i stand til å anvende reparasjonsstrategier (Dole m.fl., 1991).

For hver av disse fem hovedtypene henviser Dole m.fl. (1991) til forsking der det er blitt rapportert fremgang i elevenes lesekompetanse etter en har arbeidet med å lære elever disse strategiene. Blant annet refererer de til en studie hvor elever som var blitt gitt strukturert opploering i å lage spørsmål gjorde det bedre på en forståelsestest enn elever som bare ble bedt om å lage spørsmål eller om å lese teksten om igjen. 
Angående verdien av sjangerkunnskap henviser Dole m.fl. (1991) til oversiktsartikler som finner at kunnskap om tekststruktur hjelper lesere til å skille viktig fra uviktig informasjon samt å kunne organisere og senere gjenkalle informasjon. Denne påstanden blir bekreftet av Langer (1986) sin studie av 8 og 11 år gamle eleveres lesekompetanse hvor hun spesifikt inkluderte faglige tekster. Dole m.fl. (1991) finner videre at dyktige leseres kjennskap til teksters struktur bedrer deres gjenkallelse av hovedideer og fakta samt generell forståelse. De refererer blant annet til studier som finner at "lesere som kan identifisere og bruke en tekst sin hovedstruktur ser ut til å kunne gjenkalle mer enn de som ikke kan" (s.243, min oversettelse). Mortensen-Buan (2006) hevder at når en leser kan kjenne igjen teksters mønstre eller strukturer så kan det lette forståelsesarbeidet.

Verdien av et kjennskap til sjanger og struktur kom også frem i et israelsk forskningsprosjekt hvor eksperimentrapporter ble forsøkt brukt i naturfagopplæringen i 10. - 12. klasse (Baram-Tsabari \& Yarden, 2005; Brill, Falk \& Yarden, 2004). Forskerne tok her et antall autentiske eksperimentrapporter (innen utviklingsbiologi) og forkortet og forenklet disse. Disse forenklede eksperimentrapportene ble så brukt med 142 av elevene i arbeidet med å lære utviklingsbiologi. En kontrollgruppe på 130 elever leste en populærvitenskapelig artikkel om samme eksperiment. Ifølge forskernes analyser genererte elever som leste forenklede autentiske eksperimentrapporter mer vitenskapelig kritikk og flere og bedre ideer for videre eksperimenter elevene i kontrollgruppen (Baram-Tsabari \& Yarden, 2005). Forskerne fremsatte den hypotesen at tekststrukturen i eksperimentrapporten (IMRaD: Introduction, Method, Results and Discussion) fungerte organiserende for elevenes tenkning.

I det israelske prosjektet ble det brukt omskrevne og forenklede eksperimentrapporter. Det er vanskelig å tenke seg annet enn at autentiske eksperimentrapporter er for krevende for elever på 1. - 11. trinn. Men trening i lesing av argumenterende naturfaglige tekster er viktig for deltagelse i sosiovitenskapelige debatter. En mulighet er da først å la elevene skrive eksperimentrapporter basert på utforskende prosjekter. Deretter vil elevene gis oppgaver knyttet til lesing av hverandres eksperimentrapporter. I et norsk prosjekt med to naturfagklasser på 9. trinn (Anonym m.fl., 2005) var erfaringen at elevene genererte relevante kritiske vurderinger fra lesing av hverandres rapporter fra åpne forsøk.

\section{HVORDAN KAN VI LAERE ELEVENE Å LESE MED FORSTÅELSE?}

De fem typene lesestrategier identifisert av Dole m.fl. (1991) er delvis svært generelle, og listen er mulig å utdype og supplere med flere strategier. I norskspråklig bok som er under trykking identifiserer Roe (2008) 15 konkrete lesestrategier basert på en gjennomgang av internasjonal litteratur på feltet. De fem strategiene Dole m.fl. (1091) identifiserte fokuserer på strategiens formål. I litteraturen om lesestrategier er det også vanlig å skille mellom strategier til bruke $i$ forkant av lesingen, underveis, og $i$ etterkant av lesingen (Mortensen-Buan, 2006; Bryant m.fl., 1999). En slik sekvensiell inndeling kan være fruktbar når læreren skal tenke tilrettelegging i lesingens ulike faser, selv om mange strategier kan komme til anvendelse i ulike faser av lesingen (Langer, 1986). Eksempler på strategier til bruke $i$ forkant av lesingen er repetisjon og aktivering av egen forkunnskap i emnet (Bryant m.fl., 1999; Dole m.fl., 1991; Fielding \& Pearson, 1994; Gregg \& Sekers, 2006; Langer, 1986; Quiocho, 1997; Schmidt, 1999), bevisstgjøre seg selv på hvorfor en vil lese teksten og hva en håper å få ut av lesingen (Mortensen-Buan, 2006), etablering av forventninger til teksten samt raskt gjennomsyn av teksten for å få et inntrykk av testens struktur og innhold (Gregg \& Sekers, 2006; Mortensen-Bua, 2006). Etablering av forventninger til en tekst henger igjen sammen med kjennskap til sjangeren.

Eksempler på strategier til bruk underveis i lesingen er generering av spørsmål til seg selv med fokus på identifisering av hovedpoeng i avsnitt og seksjoner, sammenlikning av poeng i teksten med innhold i andre deler av teksten og med egen forforståelse, samt overvåking av egen forståelse 
og eventuelle hull i forståelsen (for eksempel på grunn av ukjente ord, feillesing eller fordi teksten fremstår som inkonsistent eller tvetydig) (Bryant m.fl., 1999; Dole m.fl., 1991; Fielding \& Pearson, 1994; Gregg \& Sekers, 2006; Mortensen-Buan, 2006; Quiocho, 1997). Når manglende forståelse oppdages, slik vi alle gjør når vi leser litt krevende tekster, så inkluderer underveisstrategier ulike reparasjonsstrategier. Noen muligheter her er å forsøke å identifisere vanskelige ord og skaffe seg forklaringer på disse, vurdere egen forforståelse samt konsultere andre kilder (Dole m.fl. 1991; Mortensen-Buan, 2006).

Strategier til bruk $i$ etterkant har som formål å fremme bearbeiding av teksten gjennom transformasjon (reformulering) av tekstens innhold (Bryant m.fl., 1999; Dole m.fl., 1991; Fielding \& Pearson, 1994; Gregg \& Sekers, 2006; Mortensen-Buan, 2006; Quiocho, 1997). Slik bearbeiding eller transformasjon kan gjøres visuelt gjennom å lage tankekart eller skisser, muntlig gjennom oppgavebaserte samtaler om teksten i toergrupper, grupper eller samlet klasse, samt skriftlig gjennom å lage ulike typer stikkordslister og oppsummeringer.

Gitt at vi tror at elevens lesekompetanse kan fremmes gjennom opplæring i lesestrategier og aktuelle sjangre, hvordan kan vi så tilrettelegge for opplæring i disse? Litteraturen inneholder her en rekke råd (Bryant m.fl., 1999; Dole m.fl., 1991; Fielding \& Pearson, 1994; Helgevold \& Engen, 2006; Mortensen-Buan, 2006; Roe, 2008; Wellington \& Osborne, 2001). For å øke elevenes motivasjon for lesingen hevder flere forskere at en bør gi rom for lesing av ulike typer fagtekster, samt gi rom for at elevene kan være med å velge hvilke tekster som skal leses (form og tema) innenfor rammer satt opp av lærer (Bråten, 2007; Fielding \& Pearson, 1994; Guthrie, Wigfield, \& Perencevich, 2004; Helgevold \& Engen, 2006; Mortensen-Buan, 2006). Det er viktig også å synliggjøre et behov for lesingen (Mortensen-Buan, 2006), samtale med elevene om hvorfor en skal lese en tekst, og gjerne fokusere både på læring gjennom lesing og lære å lese (Guthrie m.fl., 2004). Når en arbeider med leseopplæring anbefaler Mortensen-Buan (2006) at elevene presenteres for en ny lesestrategi av gangen. Når denne er etablert kan en skifte fokuset til en ny lesestrategi. I denne opplæringen bør en så samarbeid med andre faglærer slik at elevene får se hvordan strategien kan brukes i møte med ulike typer tekster, og slik at det faktisk blir satt fokus bare på en lesestrategi om gangen.

\section{Aktivering av forhåndskunnskaper}

Aktivering av forhåndskunnskap ble ovenfor nevnt som en strategi som mange anbefaler brukt $\mathrm{i}$ forkant av lesingen. Nødvendige forkunnskaper kan aktiveres i forkant av lesingen for eksempel gjennom samtaler eller skriving ("press-skriving") om "hva jeg vet om ..." (Maagerø, 2006; Wellington \& Osborne, 2001). Relevant faglig forankring i eksisterende kunnskap en forutsetning for og kjennetegnet på meningsfull læring av nytt materiale. I naturfaget er det her viktig å fremme forankring både i naturvitenskapelige begreper og i naturobservasjoner. Dette fordi naturvitenskaplig kunnskap inngår i større begrepsstrukturer samtidig som disse jo beskriver størrelser og prosesser i naturen. Å forstå en naturfaglig teori eller tekst vil derfor alltid innebære at en kan relatere og forankre den nye teorien både til eksisterende teori og til den delen av naturen som den nye teorien eller forklaringen omhandler. Det kan derfor være ønskelig å gjøre elevøvelser, feltarbeid, demonstrasjoner eller å studere bilder og illustrasjoner av fenomener elevene er ukjente med i forkant av lesingen (for eksempler bilder fra mikroskop og teleskop). Her ligger det også et viktig potensial til å motivere elevene gjennom å la dem få oppleve naturen på nært hold og få en positiv relasjon til denne.

For lesing av naturfaglige tekster vil naturfaglige begreper selvfølgelig være viktig forkunnskap. Samtidig er målet at elevene skal kunne bruke lesing til å lære naturfag. Motsetningen her er bare tilsynelatende. Fagbegreper er ikke noe elevene kan eller ikke kan - alt eller ingenting. Bryant m.fl. (1999) peker på at det finnes ulike nivåer av forståelse: fra "har aldri sett ordet før", "har hørt det, men husker ikke hva det betyr", "kan lese det og tror det handler om..." til "jeg kjenner godt til det ordet" (s. 296). Denne oppfatningen stemmer overens med en konstruktivistisk forståelse av 
læringsprosesser. Lesing av naturfaglige tekster vil innebære bearbeiding av naturfaglige begreper elevene skal lære. Samtidig kan vi ikke forvente at de skal lære begrepene gjennom lesing alene. Lesingen må foregå innefor en bredere didaktisk ramme.

En kjent slik didaktisk ramme for bruk på barne- og ungdomstrinnet er $\underline{K}-\underline{W}-\underline{L}$ : "What I Know, What I Want to Learn, What I Have Learned" (Helgevold \& Engen, 2006; Quiocho, 1997; Schmidt, 1999; Wellington \& Osborne, 2001). Her skal elevene først gjøre notater på et ark med disse overskriftene og derigjennom få fremkalt og bli bevisst egne forkunnskaper. Deretter skal elevene identifisere spørsmål som kan gjøre videre arbeid med lesing, elevøvelser og andre aktiviteter mer fokusert og bevisst. Til slutt skal de transformere stoffet de har arbeidet med til en oppsummerende liten fagtekst. Gregg og Sekers (2006) rapporterer om vellykket bruk av dette rammeverket under arbeid med naturgeografi og leseopplæring på tredje til sjette trinn.

Et annet kjent rammeverk er CORI (Concept-Oriented Reading Instruction), hvor et hovedpoeng er å kombinere læring av lesestrategier med læring av fag. De hevder at elevene er mer motiverte for læring av lesestrategier når lesingen er knyttet til faglige mål, samtidig som læring av faget styrkes gjennom elevenes økte evne til å lese fagtekster med forståelse. I boken "Motivating reading comprehension" presenterer Guthrie m.fl. (2004) forskning og klasseromserfaringer med CORI på barnetrinnet. Boken er særlig relevant for naturfaget da elevene her arbeider med læringsmål innen biologi og kombinerer leseaktiviteter med undersøkende praktisk arbeid. Rammeverket har fire fokusområder: instruksjon i lesestrategier, undersøkende naturfagaktiviteter, motiverende prosesser samt aktiviteter som integrerer elevenes innsikter fra lesingen og det praktiske arbeidet.

\section{Eksplisitt undervisning}

Et poeng som fremheves i litteraturen er at mange elever trenger å bli undervist eksplisitt i lesestrategier og sjangertrekk (Bryant m.fl., 1999; Dole m.fl., 1991; Fielding \& Pearson, 1994; Gregg \& Sekers, 1999; Maagerø \& Tønnesen, 2006; Martin, 1993): "The more explicit an instructional cue, the more likely students are to infer a teacher's intended curricular goals unambiguously" (Dole m.fl., 1991, s.252). Noen elever plukker opp lesestrategier og sjangertrekk av seg selv gjennom møte disse. Flere har hevdet at mangel på eksplisitt fokus på lesestrategier og sjangertrekk svekker mulighetene for barn som ikke møter mer formelle skriftkulturer hjemme (Martin, 1989; Wallace, Hand, \& Prain. 2004). Skal vi fremme lesekompetansen hos barn fra alle typer hjem kan vi derfor gjøre barna en bjørnetjeneste hvis vi tenker at vi ikke ønsker å pådytte dem andres lesestrategier og sjangre men la dem få lov å utvikle seg sine egne veier.

Internasjonalt har det her vært en diskusjon om hvorvidt språkbruk best læres gjennom eksplisitt instruksjon i strukturer og former eller om språkbruk ikke kan undervises i men må læres gjennom erfaring og deltagende bruk (Purcell-Gates, Duke \& Martineau, 2007). Purcell-Gates m.fl. (2007) fremholder at de fleste teoretikere holder en mellomposisjon der erfaring og eksplisitt instruksjon hevdes å måtte kombineres. Mortensen-Buan (2006) peker her på at opplæring i lesestrategier må kombineres med meningsfylte leseaktiviteter for å ha god effekt. Når det gjelder sjangertrekk hevder flere (Martin, 1993; Purcell-Gates m.fl., 2007) at forskningen entydig viser at eksplisitt undervisning i tekststrukturer kan forbedre forståelsen av slike. De peker også på at det er enighet om at bruk av autentiske tekster er essensielt for å lære sjangre.

Men hvordan går en så frem for å undervise elevene eksplisitt i lesestrategier og sjangertrekk? På samme måte som med andre læringsstrategier (Elstad \& Turmo, 2006) er det særlig to arbeidsmåter som blir fremhevet i litteraturen: modellering kombinert med forklaring samt stillasering kombinert med veiledning (Dole m.fl., 1991; Fielding \& Pearson, 1994; Helgevold \& Engen, 2006). Modellering innebærer at lærer demonstrerer den nye lesestrategien (Mortensen-Buan, 2006), for eksempel ved å lese høyt fra en naturfaglig tekst projisert slik at alle kan se den (Maagerø \& Tønnesen, 2006). Samtidig forklarer læreren høyt hvordan hun tenker når hun bruker strategien, for 
eksempel når hun ser igjennom tekstens form og innhold, understreker vanskelige ord eller spør seg selv hva poenget i teksten er her. Modellering bør alltid kombineres med eksplisitt forklaring av strategien slik at ikke elevene må gjette seg frem til hva hovedideen i strategien er. På tilsvarende måte kan en bruke teksteksempler til å demonstrere en sjangers hovedtrekk.

Stillasering innebærer at elevene får oppgaver som hjelper dem å bruke den nye strategien eller sjangeren. Aktuelle eksempler er formulering og innlevering av "hva tror jeg denne teksten handler om?"-spørsmål, tabell for innfylling av vanskelige ord eller overskrift for hvert avsnitt, og oppgaver der elevene skal skrive eller samtale om "hva lærte jeg av fakta" eller forklare tekstens innhold med egne ord. Wellington og Osborne (2001) presenterer en rekke oppgavetyper og rammeverk som kan fremme lesing med forståelse i ulike sjangre i naturfaget. Spesielt fremhever de betydningen av å gi spesifikke og ikke generelle leseinstruksjoner. Spesifikke leseinstruksjoner spesifiserer tydelig hva eleven skal gjøre, for eksempel "Finn og marker alle referanser til sølvbromid" (s. 44). En generell instruksjon vil mangle konkretisering, som i instruksjonen "Les hjemme og ta notater". De peker også på at ulike typer tekst ofte krever ulike typer stillas og gir eksempler på dette. Ved bruk av stillas er det viktig å undersøke om elevene har forstått den aktuelle lesestrategien og veilede dem til økt forståelse. Det er også viktig etter hvert å trekke tilbake stillaser når eleven er moden for å lese uten. I litteraturen finnes det en mengde videre råd og ideer til modellering, stillasering og kreative undervisningsideer for elever ulike aldersgrupper (Bryant m.fl., 1999; Elstad \& Turmo, 2006; Fielding \& Pearson, 1994; Helgevold \& Engen, 2006; Gregg \& Sekers, 1999; Quiocho, 1997; Roe, 2008; Schmidt, 1999). Et generelt råd er likevel å huske på at for de fleste av oss er det få aktiviteter som er mer aktiverende enn muntlig samtale, spesielt i møte med "kjedelige tema".

Mange realfaglærere har erfaring med å kombinere modellering og stillasering fra undervisning i bruk av bestemmelsesnøkler, balansering av kjemiske reaksjonslikninger og problemløsning i fysikk og matematikk. Når elevene her skal lære nye løsningsmåter eller løsningsstrategier, er det vanlig at læreren modellerer den nye algoritmen gjennom å vise et eksempel på tavlen. Dette kombineres så (ideelt sett) med en forklaring av ideen eller matematikken i den nye algoritmen. Etterpå skal elevene bruke den nye strategien selv (men matematiske algoritmer skal de bruke mindre fleksibelt enn de bør gjøre med lesestrategier). Da kan de i begynnelsen trenge litt hjelp i form av tilrettelagte oppgaver og halvferdig utfylte oppsett eller annet i tillegg til veiledning.

En aktuell utfordring i forhold til leseopplæring i naturfag er læreres bruk av oppgaver knyttet til leseaktiviteter. Mange naturfaglærere ber gjerne elevene lese i læreboken og deretter svare på oppgavene knyttet til kapittelet. Som påpekt i del 1 av denne dobbeltartikkelen (Kolstø, 2009), tyder forskning på at elever her ofte velger å lese oppgavene først, og så lete rundt i teksten for å finne det rette svaret (Quiocho, 1997; Mortensen-Buan, 2006; Helgevold \& Engen, 2006; Skjelbred, 2006). Dette er en observasjon jeg selv har gjort i mange naturfagklasserom. Spesielt når oppgavene bare etterspør faktapreget informasjon kan elevene vurdere det som mindre relevant å bruke et bredt repertoar av lesestrategier. Brill, Falk og Yarden (2004) hevder at lesing med forståelse fremmes av at elevene leser igjennom hele teksten før de begynner å arbeide med oppgavene. Alternativt kan en særlig på høyere klassetrinn gjøre bruk av mer åpne oppgaver som for eksempel å lage oppsummeringer.

I tillegg til undervisning i sjangertrekk og lesestrategier anbefaler Maagerø (2006) å samtale med elevene om betydningen av abstrakte ord som ikke er fagord, slike som relasjon, definisjon, klassifikasjon, argumentere og systematisere. Dette er ord som ikke alle kjenner, men som likevel ikke alltid er forklart i lærebøkene (Maagerø, 2006).

I arbeidet med leseopplæringen er det som i alt didaktisk arbeid også viktig at lærerens tilrettelegging for læring bygger på kunnskaper om elevenes forkunnskaper. Elevenes begynnende lesekompetanse kan for eksempel kartlegges gjennom å lytte til elever når de leser høyt samt samtale med dem om lesing (Mortensen-Buan, 2006). 


\section{FORSLAG TIL FOKUS FOR LESEOPPLARING I NATURFAGET}

Litteraturgjennomgangen ovenfor tyder på at opplæring i lesing av fagtekster kan fremme elevers lesekompetanse. Læringsstrategier og lesing som grunnleggende ferdighet er inkludert som tema i den Norske læreplanreformen. I del 1 av denne dobbeltartikkelen fant jeg likevel at leseopplæring er lite vektlagt i den nye læreplanen i naturfag. En gjennomgang av litteratur i del 1 gav også klare indisier på at elevene strever med å lese naturfaglige tekster og at leseopplæring er lite vektlagt i naturfagundervisningen i mange land. Som et utgangspunkt for en sterkere vektlegging av lesing $\mathrm{i}$ naturfag vil jeg derfor legge frem et forslag til mål for opplæringen i lesing av naturfaglige tekster. På bakgrunn av diskusjonen tidligere i artikkelen fokuserer forslaget på sjangre det bør arbeides med samt demonstrerbare lesestrategier for ulike hovedtrinn.

\section{Forslag til sjangre i leseopplæringen i naturfag}

Et tydeligere fokus på leseopplæring i naturfag forutsetter en bevissthet om hvilke sjangre en ønsker å lære elevene opp i. Martin (1993) har identifisert følgende sjangre som sentrale i naturvitenskap: begrepsoversikter (repport), forklaringer (explanations), eksperimentprosedyrer (experiment - procedural), eksperimentrapporter (experiment - recounts), utredning (exposition) og biografi (biography). Naturfaglige begrepsoversikter finnes også som tekster som begrenser seg til å beskrive ytre observerbare kjennetegn ("reven har hale og spiser mus"). Slike tekster brukes gjerne på lavere klassetrinn og kan betegnes som beskrivelser. Både Martin (1993) og Veel (1997) peker på at lærebøker i naturfag i stor grad inneholder de faktabeskrivende sjangrene begrepsoversikter, forklaringer og eksperimentprosedyrer. Viktigheten av å kunne lese for å lære både på skolen og senere i livet tilsier at disse sjangrene bør gis oppmerksomhet i leseopplæringen. I tillegg til $e k$ sperimentprosedyrer brukes i naturfaget også andre prosedyretekster som sikkerhetsinstrukser og bruksanvisninger for teknisk utstyr. Da elever vil kunne møte slike i yrke og fritid senere i livet er disse også inkludert i forslaget. De to argumenterende sjangrene eksperimentrapport og utredning ser ikke ut til å være like vanlig å vektlegge i naturfag. Med økt tilgang til Internett er det her sannsynlig at miljøaktivister og engasjerte lekfolk leser eksperimentrapporter i større grad enn før. Eksperimentrapport og utredninger presenteres også ofte i media. Når det gjelder utredninger så forekommer disse som rene naturfaglige diskusjoner innen naturvitenskapelige fagfelt, men også som ekspertutredninger og debattinnlegg fra lekfolk. Eksempler her er offentlige miljøutredninger og leserinnlegg i aviser. Da argumenterende sjangrene er sentrale både i naturvitenskapene og i sosiovitenskapelige debatter bør disse inkluderes i allmenndannende kurs i naturfagopplæringen. Biografier er mindre relevant i forbindelse med naturfagopplæringen og sosiovitenskapelige kontroverser og er derfor ikke inkludert.

Naturvitenskapen benytter også andre sjangre enn de som her er diskutert, blant annet teoretiske artikler, oversiktsartikler og håndbøker. Veel (1997) og Martin (1993) identifiserer også ulike undergrupper av begrepsoversikter, forklaringer og utredninger. Krav til oversiktlighet og relevans for lekfolks møter med naturfaglige tekster gjør at jeg vurderer disse undergruppene som mindre relevante for naturfagopplæringen.

I tillegg til at elevene blir kjent med sjangeres sosiale formål trenger de også å bli kjent med deres typiske oppbygging og begrunnelse for denne oppbyggingen. En oversikt over typisk struktur for ulike sjangre brukt i skolens naturfag finnes hos Veel (1997). Wellington og Osborne (2001) tilbyr ulike råd for opplæring i slike strukturer.

I naturfag er det også viktig at elevene blir kjent med hvordan påstander på ulike epistemiske nivå ofte inngår i ulike sjangre. Forklaringer og prosedyretekster inneholder typisk ukontroversielle påstander om naturen. Eksperimentrapporter og debattinnlegg vil derimot normalt innholde tentative påstander som teksten argumenterer for. Det blir dermed viktig at elevene ser at tekster i ulike sjangre gjerne må leses ulikt: I en forklarende tekst kan en spørre om forklaringen gir mening. Når en leser en eksperimentrapport eller et debattinnlegg må en spørre seg om argumentene 
Tabell 1: Forslag til sjangre i leseopploeringen i naturfag

\begin{tabular}{|c|c|c|}
\hline $\begin{array}{l}\text { Naturfaglige sjan- } \\
\text { gre }\end{array}$ & Sosialt formål & Typisk struktur \\
\hline Beskrivelse & Beskrive objekter i naturen & Beskrivelse \\
\hline Begrepsoversikt & $\begin{array}{l}\text { Beskrive en klasse av objekter i } \\
\text { naturen }\end{array}$ & Generelt konstatering, beskrivelse \\
\hline Forklaring & Forklare prosesser i naturen & $\begin{array}{l}\text { Identifisering av fenomen, steg-for- } \\
\text { steg forklaring }\end{array}$ \\
\hline Prosedyretekster & $\begin{array}{l}\text { Muliggjøre en vitenskapelig aktiv- } \\
\text { itet }\end{array}$ & Formål, utstyr, steg \\
\hline Eksperimentrapport & $\begin{array}{l}\text { Fremme en begrunnet påstand } \\
\text { om naturen }\end{array}$ & $\begin{array}{l}\text { Introduksjon, metode, resultater } \\
\text { (data), diskusjon }\end{array}$ \\
\hline Ekspertutredning & $\begin{array}{l}\text { Overbevise om et saklig } \\
\text { synspunkt }\end{array}$ & $\begin{array}{l}\text { Påstand, argumenter, forsterket } \\
\text { påstand }\end{array}$ \\
\hline Debattinnlegg & Overbevise om et synspunkt & $\begin{array}{l}\text { Sak, avvisning av motstanderes syn, } \\
\text { argumenter for eget syn, anbefaling }\end{array}$ \\
\hline
\end{tabular}

er relevante og holdbare. Ved å inkludere argumenterende sjangre i naturfagopplæringen vil elevene lettere kunne se at naturvitenskapelig kunnskap kan være alt fra usikre foreløpige hypoteser til pålitelige etablert fakta. Detter er viktig innsikt i møte med sosiovitenskapelige kontroverser (Anonym, 2000). Når elevene skal lære en sjanger å kjenne, kan det være en fordel å sammenlikne ulike sjangre for dermed å kunne se hvordan de skiller seg fra hverandre, for eksempel sammenlikne forklaring og eksperimentrapport. I tabell 1 presenteres en oversikt over de foreslåtte sjangre samt deres hovedstruktur basert på Veel (1997).

\section{Forslag til progresjon i opplæring lesestrategikompetanser i naturfag}

For å lese tekster i sjangrene ovenfor med forståelse trenger elevene lesestrategier. I utgangspunktet er lesestrategier mentale strategier en leser bruker for seg selv, og er derfor som oftest ikke observerbare. Det er likevel slik at mange lesestrategier innebærer aktiviteter som kan gjøres synlige gjennom skrift eller tale. Eksempelvis kan en oppsummering gjøres som en stille gjennomtenkning, men også som en skrevet tekst. I tråd med stillasering som undervisingsprinsipp kan det være lærerikt og dermed ønskelig at elever utfører oppgaver som innebærer synlig bruk av viktige lesestrategier. Målene for lesekompetanse er derfor formulert som demonstrerbare kompetanser i forslaget i tabell 2. Dette gjør dem både konkrete og observerbare. I tillegg gjør det dem kompatible med fokuset på demonstrerbarhet og evaluering i det nye norske læreplanverket. Identifiseringen av en progresjon gjennom utdanningsløpet i forslaget er i tråd med Stortingsmelding nr. 30 (Utdannings- og forskningsdepartementet, 2004) som lå bak læreplanreformen i Norge. Her påpekes det at i det nye læreplanverket må "kravene til [de grunnleggende] ferdighetene være tydelige på ulike trinn gjennom hele grunnopplæringen" (s.33) og "Elevene trenes mer systematisk opp i grunnleggende ferdigheter" (s.35).

Forslagene til lesestrategikompetansene i tabell 2 er basert på Dole m.fl. (1991) sine seks hovedtyper av lesestrategier, inkludert viktigheten av å aktivere egne forkunnskaper. Sifrene foran hver kompetanse refererer således til disse hovedtypene av lesestrategier (0. aktivere forhåndskunnskap, 1. bestemme viktighet, 2. oppsummere informasjon, 3. trekke slutninger, 4. generere spørsmål, 5 . overvåke egen forståelse og bruke reparasjonsstrategier). I lokalisering av lesestrategikompetanser og sjangre på trinn er det tatt hensyn til signaler om sjangre i naturfagplanen, samt viktigheten av at taksonomisk nivå på mentale operasjoner er tilpasset de ulike trinn. Det er også tatt høyde for at elever på ulike nivå kan og bør nyttegjøre seg alle hovedtyper lesestrategier, men på ulike kompleksitetsnivå (Langer 1986). 
Tabell 2: Forslag til progresjon i opplcering lesestrategikompetanser i naturfag. Tallkoder refererer til Dole m.fl. (1991) sine hovedtyper av lesestrategier.

\begin{tabular}{|c|c|}
\hline I forhold til ulike typer naturfaglige tekster skal elevene kunne & Sjangre \\
\hline \multicolumn{2}{|l|}{ 2. og 4. klassetrinn } \\
\hline $\begin{array}{l}\text { o Sette ord på egen forhåndskunnskap } \\
\text { o Identifisere vanskelige ord, de ulike delene av sammensatte ord samt } \\
\text { prøve å uttale disse } \\
1 \text { Identifisere informasjon i form av fakta } \\
2 \text { Lage oppsummeringer i form av enkle faktatekster } \\
3 \begin{array}{l}\text { Identifisere enkle forskjeller mellom innholdet i en tekste og egen } \\
\text { nedskrevne forforståelse } \\
4 \text { Formulere spørsmål som kan besvares med fakta fra teksten } \\
5 \text { Identifisere ord og avsnitt en ikke forstår og foreslå enkle strategier } \\
\text { for å komme videre }\end{array}\end{array}$ & $\begin{array}{l}\text { - Beskrivelser } \\
\text { - Enkle prosedyrer } \\
\text { - Beskrivende eksperi- } \\
\text { ment-rapporter } \\
\text { - Enkle forklaringer }\end{array}$ \\
\hline \multicolumn{2}{|l|}{ 7. klassetrinn } \\
\hline $\begin{array}{l}\text { o Fortelle om forventinger til innhold } \\
1 \text { Identifisere hovedpoeng i forklarende tekster, og hovedpåstand og } \\
\text { underbygginger i debattinnlegg } \\
2 \text { Lage oppsummeringer i form av lister, tegninger, tekster og tankekart } \\
3 \text { Sammenlikne innholdet i enkle tekster med egen forståelse } \\
4 \text { Formulere spørsmål om begreper og forklaringer i teksten } \\
5 \text { Identifisere ord og avsnitt en ikke forstår og foreslå enkle strategier } \\
\text { for å komme videre }\end{array}$ & $\begin{array}{l}\text { - Enkle begreps-over- } \\
\text { sikter } \\
\text { - Enkle prosedyre- } \\
\text { tekster } \\
\text { - Enkle multimodale } \\
\text { forklaringer } \\
\text { - Enkle debattinnlegg }\end{array}$ \\
\hline \multicolumn{2}{|l|}{ 10. klassetrinn } \\
\hline $\begin{array}{l}1 \text { Identifisere ulike argumenter og begrunnelser } \\
2 \text { Lage oppsummeringer av forklaringer og eksperimentrapporter } \\
3 \text { Sammenlikne innhold med egen tenkning og vurdere sammenheng } \\
\text { mellom argument og påstand, eksempler og forklaring } \\
4 \text { Formulere spørsmål om forskjeller og likheter på ulike begreper og } \\
\text { argumenter i en tekst } \\
5 \text { Greie ut om ulike typer av problem og mulige strategier for å komme } \\
\text { videre }\end{array}$ & $\begin{array}{l}\text { - Begrepsoversikter } \\
\text { - Prosedyretekster } \\
\text { - Forklaringer } \\
\text { - Enkle eksperiment- } \\
\text { rapporter } \\
\text { - Debattinnlegg }\end{array}$ \\
\hline \multicolumn{2}{|l|}{ 11. klassetrinn } \\
\hline $\begin{array}{l}\text { o Fortelle om forventinger til innholdet i ulike typer naturfaglige tekster } \\
1 \text { Identifisere hovedpoeng, argumenter og direkte og indirekte empirisk } \\
\text { underbygging } \\
2 \text { Lage oppsummeringer } \\
3 \text { Vurdere kvaliteten på innholdet og av påstanders pålitelighet } \\
4 \text { Formulere spørsmål som ikke besvares i teksten } \\
5 \text { Peke på hva en ikke forstår, identifisere type av problem og foreslå } \\
\text { ulike strategier for å komme videre }\end{array}$ & $\begin{array}{l}\text { - Som på 10. trinn } \\
\text { - Ekspertutredninger }\end{array}$ \\
\hline
\end{tabular}


I tabell 2 er også de ulike sjangrene i tabell 1 fordelt på ulike trinn. Angående tilgjengelighet av ulike sjangre for ulike aldersgrupper finner Langer (1986) at allerede 8-åringer greier å skille mellom fortellende og naturfaglige beskrivende tekster. Jeg har ikke funnet andre sammenliknende studier av barns kompetanse i lesing av ulike typer naturfaglige tekster på ulike alderstrinn. Basert på sin studie av barns lesing og skriving konkluderer Langer (1986) at de samme typer resoneringsoperasjoner (reasoning operations) inngår i lesing og skriving. Jeg har derfor brukt Martins (1989) resultater som utgangspunkt for plassering av sjangre på ulike trinn. Martin fant i sin studie at elevene tidlig skrev enkle prosedyrer og beskrivende eksperimentrapporter. Derimot var det få elever i tidlige skoleår som prøvde seg på naturfaglige forklaringer eller andre tekster med generelle påstander. Han hevder også at elevene fant det mer krevende å skrive argumenterende tekster.

Det er også viktig at vi i naturfag ikke arbeider med sjangre med epistemiske trekk som elevene ikke er modne for å forstå. Implisitt i eksperimentrapport som sjanger, samt i naturfagplanen for 10. og 11. trinn, ligger det en forestilling om at naturfaglige kunnskaper bygger på empiri og diskusjoner om dennes styrke. I følge forskningen til Kitchener og King (1981) vil også elever som er eldre enn 18 år ofte ha forestillinger om kunnskapers begrunnelser som ikke inkluderer argumentasjon og regler for vurdering av evidens. Det er derfor naturlig å vektlegge beskrivende og enkle forklarende sjangre på småskoletrinnet, og vente med å trekke inn argumenterende sjangre til senere i naturfagopplæringen.

For å tydeliggjøre konkrete ansvar for naturfaglærere på ulike trinn har jeg valgt å identifisere ulike kompetansemål for lesestrategier på ulike alderstrinn. I tillegg er det pedagogisk riktig å fokusere på utvikling av en eller noen får lesestrategier om gangen. Det vil selvfølgelig være nødvendig at lærere på de ulike trinn observerer elevenes kompetansenivå og vurderer om de bør arbeide på nytt med lesestrategier og sjangre foreslått på lavere nivå. Langer (1886) finner i sin studie av 8 og 14 år gamle barn at de to aldersgruppene benyttet de samme generelle strategiene når de prøvde å forstå det de leste. I tabell 2 er derfor ulike typer lesestrategier tatt med på alle alderstrinn, men med ulike krav til kompleksitet i anvendelsen.

Forslagene til lesestrategikompetanser i tabell 2 er selvfølgelig ikke utfyllende i forhold til det vi har av erfaringer om lesestrategier og om opplæring i lesing av fagtekster med forståelse. De er ment som et første steg mot et naturfag der leseopplæring regnes som en naturlig del av faget. På samme måte som med kompetansemålene i naturfagplanen kan disse også leses som utkast til oppgavetyper naturfaglærere kan gi sine elever. Kanskje kan forslagene derved gjøre det lettere å komme i gang med leseopplæring samtidig som de kan øke repertoaret av oppgaver naturfaglærere gir til sine elever i forbindelse med leseaktiviteter.

En viktig side ved mange naturfaglige tekster er multimodalitet. Det vil her være ønskelig at elevene blir bevisst muligheter for å tydeliggjøre ulike typer av informasjon som ligger i forskjellige språklige og grafiske representasjoner (ofte kalt modal affordans). Kunnskap om multimodalitet er likevel ikke tilstrekkelig, men bør suppleres med lærers modellering og forklaring av hvordan en leser, flytter blikket og vurder når en leser multimodale tekster. Ved lesing av naturfaglige tekster på Internett må en i tillegg ofte velge om en skal bruke en hyperlenke og dermed gå ut av en tekst for å få mer utdypende informasjon. Vurdering av kilde og faglig pålitelighet er også mer krevende i slike tekster, blant annet på grunn av stor variasjon i kvalitet på utøvelse av redaktøransvar og ulik epistemisk status til fremsatte påstander. Lesing og vurdering av tekster på Internett trenger derfor spesiell oppmerksomhet. En utdypende diskusjon av vurdering av pålitelighet til påstander i naturfaglige tekster på Internett finnes hos Kolstø m.fl. (2006).

Når en skal arbeide med lesing av fagtekster i naturfag er det også viktig å vurdere hvordan opplæring i lesing av fagtekster kan sees i sammenheng med skriveopplæringen (Maagerø \& Tønnesen, 2006). Gitt verbene som brukes i den norske læreplanen i naturfag er det tydelig at elevene skal 
lære å skrive beskrivelser, forklaringer og eksperimentrapporter, og kanskje også utredninger og debattinnlegg. Skal en lære å skrive godt i en sjanger, er det viktig å ha sett gode eksempler på sjangeren, og dette innebærer lesing. Da vi neppe antar at flertallet av elevene får behov for å skrive i særlig mange av naturfagets sjangre senere i livet, virker det rimelig å anta at skriving i naturfaglige sjangre ikke er mål i seg selv. Skriving av fagtekster i naturfag kan selvfølgelig forventes å ha overføringsverdi til skriving av fagtekster i andre sammenhenger, men det å skulle lære det gjennom naturfaget i stedet for direkte kan neppe være en hovedbegrunnelse. Mer nærliggende er det å tro, at i tillegg til testaspektet, så er formålet å bli kjent med naturfagets sjangre slik at en lettere kan lese naturfaglige tekster samt delta i ulike typer samtaler (forklaring, kritisk dialog, undersøkende dialog, argumentering) om naturfaglige emner.

\section{AVSLUTTENDE KOMMENTARER}

I denne artikkelen har jeg lagt frem noen forslag for leseopplæring i naturfag. Med utgangspunkt i resultater fra leseforskning identifiserte jeg to hovedfokus: lesestrategier og sjangerkunnskap. Forslagene innebærer lesing på naturfagets premisser gjennom fokusering på naturfaglige sjangre. I tillegg tar progresjonen i forslagene hensyn til ulike naturfaglige sjangres kompleksitet, blant annet forekomst av påstander med ulik epistemisk status. I dag er det ingen naturfagplaner for grunnopplæringen i nordiske land som inkluderer slike konkretiseringer av mål for leseopplæring. Jeg har påpekt at resultater fra leseforskning viser at elever kan ha utbytte av opplæring $\mathrm{i}$ å lese med forståelse, og at det foreligger en rekke erfaringer som signaliserer hva en slik opplæring kan innebære i praksis. Mine forslag til kompetansemål for opplæring i lesestrategier er tilpasset innedelingen i hovedtrinn i det norske skolesystemet, men innholdet tenkes å være relevant for grunnopplæring i naturfag generelt.

Den foreliggende artikkel er den andre av to artikler som fokuserer på lesingens posisjon i naturfagets rammer og innhold. Begrunnelsen for nødvendigheten av de presenterte forslag, og av økt fokus på leseopplæring generelt, ligger i drøftingen i den første artikkelen (Kolstø, 2009). En litteraturgjennomgang gav tydelige indikasjoner på at mange elever strever med å lese naturfaglige tekster, og at det er lite tradisjon for opplæring i lesing av fagtekster i naturfag og andre skolefag. En gjennomgang av den nye norske læreplanen i naturfag ble konkludert med at verb som signaliserer målsettinger for lesekompetanse nærmest er fraværende i de formulerte kompetansemål. Disse observasjonene utgjør begrunnelser for at leseopplæring bør vektlegges sterkere i naturfag. Forslagene i denne artikkelen er ment som et innlegg i debatten om hva en sterkere vektlegging kan innebære.

Hvis leseopplæring bør bli en integrert del av naturfagundervisingen blir det viktig å vurdere hvordan en slik endring av tradisjonen kan fremmes. Lærere er ofte selv ekspertlesere som bruker ulike lesestrategier intuitivt. Den kanskje viktigste endringsfaktoren vil derfor være økt bevissthet hos naturfaglærere om hvorfor lesing i naturfag er viktig, hva elevene trenger å lære, og hvordan en kan arbeide med leseopplæring i naturfag. Gjennom bevisst kjennskap til egne lesestrategier vil også naturfaglæreren kunne starte med lesestrategier hun/han selv er trygg på. Gjennom å samarbeide med andre faglærere og med foreldre kan naturfaglæreren slippe å bli sittende alene om ansvaret samt at koordinert opplæringen i lesestrategier kan gjøre slik opplæring effektiv.

Mange lærere sitter med mye erfaring med bruk av autentiske tekster fra aviser og andre media, men gjerne ikke så mye som en del av leseopplæring i naturfag. I en nordirsk studie med 50 naturfaglærere fant Jarman og McClune (2002) at flertallet av dem sporadisk gjorde bruk av avisoppslag i undervisningen, om enn ikke systematisk. I prosjektet Nileseren i Bergen kommune på 9. trinn skoleåret 2006-07 (Bergen kommune, 2007) ble det brukt ulike typer autentiske avistekster for å stimulere til lesing. En av prosjektets begrunnelser er nettopp å følge opp den norske skolereformen "Kunnskapsløftet" gjennom å øke fokuset på lesing som grunnleggende ferdighet. Flere av 
skolene som var med hevder i rapporten fra prosjektet at avislesingen var med på å støtte opp under lesing i alle fag, inkludert naturfag. En av skolene påpekte at aviser inneholdt stoff innen mange interesseområder, og at mange elever som ellers ikke ville lese var ivrige. I prosjektet inngikk også lesing av tyngre kommentar og debattstoff som kronikker og ledere. Det kan derfor se ut til at lesing av autentiske tekster representerer en uutnyttet ressurs i forhold til kontekstualisering av naturfaget, motivering av elever og realisering av naturfag som et allmenndannede fag.

\section{REFERANSER}

Anderson, J. R., Simon, H. A. \& Reder, L. M. (1996). Situated learning and education. Educational Researcher, 25(4), 5-11.

Baram-Tsabari, A., \& Yarden, A. (2005). Text genre as a factor in the formation of scientific literacy. Journal of Research in Science Teaching, 42(4), 403-428.

Bergen kommune, (2007). Rapport Nileseren - et lesestimuleringsprosjekt for 9. trinn. Bergen kommune skoleåret 2006 - 2007. Hentet 11.03.08 fra http://www.ais-vest.net/common/dokumenter/evaluering_nileser_0607_bergen

Brill, G., Falk, H. \& Yarden, A. (2004). The learning processes of two high-school biology students when reading primary literature. International Journal of Science Education, 26(4), 497-512.

Bryant, D. P., Ugel, N., Thomson, S \& Hamff, A. (1999). Instructional strategies for content-area reading instruction. Intervention in School and Clinic 34(5), 293-302.

Bråten, I. (2007). Leseforståelse - komponenter, vansker og tiltak. I Bråten, I. (Red.) Leseforståelse. Lesing i kunnskapssamfunnet - teori og praksis (s. 45-81). Oslo: Cappelen Akademisk forlag.

Dole, J. A., Duffy, G. G., Roehler, L. R. \& Pearson, P. D. (1991). Moving from the old to the new: Research on reading comprehension instruction. Review of Educational Research 61(2), 239264.

Elstad, E. \& Turmo A., (2006) (Red.). Laeringsstrategier: Søkelys på loerernes praksis. Oslo: Universitetsforlaget.

Fielding, L. G. \& Pearson, P. D. (1994). Reading comprehension: What works. Educational Leadership 51(5), 62-68.

Gregg, M. \& Sekers, D. C. (2006). Supporting children's reading of expository text in the geography classroom. The Reading Teacher 60(2), 102-110.

Guthrie, J. T., Wigfield, A. \& Perencevich, K. C. (2004). Motivating reading comprehension. Concept-oriented reading instruction. Mahwah, NJ: Erlbaum.

Helgevold, L. \& Engen, L. (2006). Fagbok i bruk: Å lese en fagtekst. I L. Helgevold \& L. Engen (Red.). Fagbok $i$ bruk (s. 6-15). Stavanger: Nasjonalt senter for leseopplæring og leseforskning.

Jarman, R. \& McClune, B. (2002). A survey of the use of newspapers in science instruction by secondary teachers in Northern Ireland. International Journal of Science Education, 24(10), 97-1020.

Kitchener, K. S. \& King, P. M. (1981). Reflective judgement: concepts of justification and their relationship to age and education. Journal of Applied Developmental Psychology, 2, 89-116.

Kjærnsli, M., Lie, S., Olsen, R. V. \& Roe, A. (2007). Tid for tunge løft. Norske elevers kompetanse $i$ naturfag, lesing og matematikk i PISA 2006. Oslo: Universitetsforlaget.

Kolstoe, S. D. (2000). Consensus projects: teaching science for citizenship. International Journal of Science Education, 22(6), 645-664.

Kolstø, S. D. (2009). Vektlegging av lesing i naturfaget. Del 1: Vil den nye norske læreplanen i naturfag øke elevenes lesekompetanse? NorDiNa, dette nr.

Kolstø, S. D., Bungum, B., Arnesen, E., Isnes, A., Kristensen, T., Mathiassen, K., Mestad, I., Quale, A., Tonning, A. S. V. \& Ulvik, M. (2006). Science students' critical examination of scientific information related to socio-scientific issues. Science Education, 90(4), 632-655. 
Kunnskapsdepartementet (2006). Laereplan i naturfag. Hentet 21.04.08 fra http://www.udir.no under Kunnskapsløftet - fag og læreplaner. Finnes også i dokumentet Læreplanverket for Kunnskapsløftet (Midlertidig utg. juni 2006): Oslo: Utdanningsdirektoratet.

Langer, J. A. (1986). Children reading and writing. Structures and strategies. New Jersey: Ablex Publishing Corporation.

Lie, S., Kjærnsli, M., Roe A. \& Turmo A. (2001). Godt rustet for framtida? Norske 15-åringers kompetanse i lesing og realfag i et internasjonalt perspektiv. Acta Didactica, 4.

Martin, J. R. (1989). Factual writing: Exploring and challenging social reality. Oxford: Oxford University Press.

Martin, J. R. (1993). Literacy in science: Learning to handle text as technology. I M. A. K. Halliday \& J. R. Martin (Red.), Writing science: Literacy and discursive power (s. 166-220). Pittsburgh, PA: University of Pittsburgh Press.

Mortensen-Buan, A.-B. (2006). Lesestrategier og metoder. I E. Maagerø \& E. S. Tønnesen (Red.). $\AA$ lese $i$ alle fag (s.165-189). Oslo: Universitetsforlaget.

Maagerø, E. (2006). Om å lese på setningsnivået. I E. Maagerø \& E. S. Tønnesen (Red.). Å lese $i$ alle fag (s. 65-87). Oslo: Universitetsforlaget.

Maagerø, E. \& E. S. Tønnesen (2006). Å lese i alle fag. I E. Maagerø \& E. S. Tønnesen (Red.). $\AA$ lese $i$ alle fag (s. 13-30). Oslo: Universitetsforlaget.

Newton, P., Driver, R. \& Osborne, J. (1999). The place of argumentation in the pedagogy of school science. International Journal of Science Education, 21(5), 553-576.

Norris, S. P. \& Phillips, L. M. (2003). How literacy in its fundamental sense is central to scientific literacy. Science Education 87, 224-240.

Purcell-Gates, V., Duke, N. K. \& Martineau, J. A. (2007). Learning to read and write genre-specific text: Roles of authentic experience and explicit teaching. Reading Research Quarterly 42(1), 8-45.

Quiocho, A. (1997). The quest to comprehend expository text: Applied classroom research. Journal of Adolescent \& Adult Literacy 40(6), 450-456.

Roe, A. (2008). Lesedidaktikk etter den første leseopploeringen. Oslo: Universitetsforlaget.

Ryder, J. (2001). Identifying science understanding for functional scientific literacy. Studies in Science Education, 36, 1-44.

Schmidt, P. R. (1999). KWLQ: Inquiry and literacy learning in science. The Reading Teacher 52(7), 789-792.

Skjelbred, D. (2006). Sjangrer og lesemåter i fagtekster. I E. Maagerø \& E. S. Tønnesen (Red.). $\AA$ lese $i$ alle fag (s. 31-46). Oslo: Universitetsforlaget.

Utdannings- og forskningsdepartementet (2003). I første rekke. Forsterket kvalitet i en grunnopploering for alle (Kvalitetsutvalget). NOU 2003:16. Oslo: Statens forvaltningstjeneste.

Utdannings og forskningsdepartementet (2004). Kultur for laering. Stortingsmelding nr. 30. Oslo: Utdannings- og forskningsdepartement.

Veel, R. (1997). Learning how to mean - scientifically speaking: apprenticeship into scientific discourse in the secondary school. I F. Christie \& J.R. Martin (Red.). Genre and institutions: Social processes in the workplace and school. London: Continuum.

Wallace, C. S., Hand, B. \& Prain, V. (2004). Writing and learning in the science classroom. Dortrecht: Kluwer Academic Publishers.

Wellington, J. \& Osborne J. (2001). Language and literacy in science education. Buckingham: Open University Press. 